\title{
War, Violence and Tyrannicide in the Book of Judith
}

\author{
BARBARA Schmitz
}

The book of Judith appears to be a book of war. In its first chapter, it starts with the war plans of the Assyrian king Nebuchadnezzar who wants to conquer the world. The book ends with Israel's big celebration of the enemy's defeat in chapter sixteen. Beside that, there are plenty of other war descriptions to be found in the book of Judith. ${ }^{1}$

But in the énd, it is not the military actions that solve the conflict, but Judith's act: Judith enters the camp of the Assyrians and kills General Holofernes by his own sword. The assassination of Holofernes is the crucial turning point in the narrative. That's why Judith's act evokes a lot of questions: Does Judith have a personal motivation to kill Holofernes? Or can it rather be seen as a politically-motivated assassination?

For that purpose, the military conflict as the background for Judith's murder will be illustrated first. Then, the most famous tyrannicide in antiquity will be introduced: Harmodius and Aristogeiton. After that, it will be discussed whether connections can be seen between the murder of Harmodius and Aristogeiton and the Judith narrative. This new context will change the military character of the book of Judith and will show that the narrative has an alternative concept of how to face violence.

\section{War in the Book of Judith}

Three different war constellations can be found in the book of Judith. The first constellation is given in the first chapter: Nebuchadnezzar against the Eastern countries. The second constella-

1 Nevertheless, the book of Judith does not present historical facts but can rather be seen as a companion of vital, political and military threats Israel had to face. These threats are combined to a new compressed version of the historical memories and a fictional narrative. 
tion is given in the second and third chapter: Holofernes against the Western countries. And finally in chapter four to sixteen: Holofernes against Israel.

At the beginning of the narrative, Nebuchadnezzar claims himself to be the dominator of the world and puts into action by conquering the Persians in the East (Judith 1). ${ }^{2}$ The following fifteen chapters describe how Nebuchadnezzar's plan is realized in the West. Therefore, the Assyrian king presents a concept to Holofernes of how to conquer the Western countries. In other words: he hands the job over to his deputy Holofernes (Jdt 2:4, 5-13). ${ }^{3}$ It is on Holofernes to subjugate the - by Nebuchadnezzar called - "disobedient" people, so that Nebuchadnezzar can personally hold a trial over the conquered people later on, as he says in his speech in chapter 2: ${ }^{17}$ Bid them have earth and water ready, ${ }^{4}$ because in my rage I am about to march on them; the feet of my soldiers will cover the whole face of the earth, and I shall plunder it. ${ }^{8}$ Their wounded will fill the valleys and the torrents, and rivers, blocked with their dead, will overflow. ${ }^{9}$ I shall lead them captive to the ends of the earth" (Jdt 2:7-9). Nebuchadnezzar's speech is stressed with violent war rhetoric revealing the fact that Nebuchadnezzar is not satisfied with just gaining the world domination. He claims to be seen as a god and demands to be treated like one as well. Implicitly, one can see that for the first time in his speech in chapter two. In 3:8; 6:2, his claim for deity is explicitly outspoken. After the triumphant and arousing speech interspersed with war rhetoric, it is time for Holofernes

2 Although the catchword "war" is mentioned in Jdt 1:5 for the first time and connected to Nebuchadnezzar, ", the king of the Assyrians", the theme "war" already comes up earlier in the Judith narrative, namely in the first verses (Jdt 1:2-4), which contain the background information. Here it is connected to the Median king Arphaxad. In Jdt 1:5, the first lines of the narrative (Jdt 1:1) reappear syntactically and introduce the major plot of the Judith narrative, namely the Nebuchadnezzar's act of war against Arphaxad. That is why the book of Judith can be regarded as a book of war.

3 The quoted and discussed biblical texts always refer to the LXX, unless otherwise noted.

4 Cf. for the Persian gesture "earth and water": Hist. 4,126.127.132; 5,17.18bis.73; 6,48.49.94; 7,2bis.131.133.138.163.233; 8,46; Lycurgus, Kata Leocratous, 71; Plutarchus, Them. 6; Polybios, Hist. 9,38; Livius, Hist. 35,17; Curtius Rufus, Hist. 3,10 . 
to act. And he does it in a rather unemotional and war pragmatic way: He calls for the Assyrian strategists, arranges the troops, examines his army and guarantees an adequate supply of baggage train (Jdt 2:14-18). Subsequently, Holofernes moves out with the troops. Soon chariots, cavaliers and horses cover the land. This image underlines the statement that Holofernes' raid already foreshadows the cruel and apocalyptical war of Nebuchadnezzar. This is also underlined by the image of the uncountable warriors described as grasshoppers and sand (Jdt 2:20, cf. 2:17). Totally intoxicated by war, brutality, destruction and seduced by the power and the confidence of victory, Holofernes is uncontrollable. Nothing can stop him, nothing is save from him. Nobody knows when and where Holofernes will appear and whether he just pass by or destroy everything. Holofernes is pictured as a hurricane running through the land with the possibility to change direction at any time. The tremendous brutality of his war clearly relates to biblical texts that focus on the end of days, the apocalypse, the day of God (cf. Jer 25:32; Amos 1-2; Ezek 38:9, 16). The known biblical topos of the "enemy from the north" is used in a parallel way (Jdt 16:3 cf. Jeremiah 4-6). The apocalyptic storm of the Northern enemy is answered by fear, horror (Jdt 2:28) and surrender by the Western people (Jdt 3:1-5, 7). ${ }^{5}$

Israel is mentioned for the first time in chapter four. Just as all the other tribes, Israel is powerless against Holofernes and his troops. But the people of Israel are the first to offer resistance. The religious and military resistance is explained in chapter four. Israel is not able to compete with the Assyrian army.

The superiority of the Assyrians and the helplessness of Israel are the foundation for Judith's act: As the elders were not convinced by Judith's plans (Judith 8), she takes matters into her own hands (Judith 10) after having prayed to God to help her to realize her plan (Judith 9). Having entered the Assyrian camp, she gains Holofernes' confidence and kills him by his own sword

5 Holofernes' raid seems unstoppable until Jdt 3:9-10: Holofernes gives his warriors a break of one month to reorganize the troops and the baggage. This break can also be seen as a narrative break as the narrative continuity slows down. This separates the first part of the Judith narrative very clearly from the rest. 
after he got himself totally alcoholized and incapable to act (Judith 11-13). Returning to her people from the camp, Judith explains her plans for "fighting" back (Jdt 14:1-5) which is immediately accomplished (Jdt 14:11-15:7, 11). As Israel is not able to compete with the Assyrian army, Judith suggests a special plan for the battle: since the Assyrians would quickly discover their murdered general, they would escape in panic (Jdt 14:1-5). Her plan works out and it is easy for Israel to put to flight the Assyrian army out of the Land of Israel (Jdt 14:11-15:7, 11).

At the end of the narrative, Judith is called the "leader of

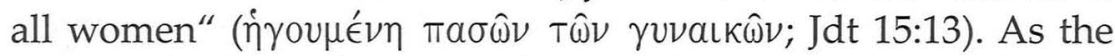
military leader, Judith is the head of the procession of peace to the house of God in Jerusalem (Jdt 15:13). This is the explicit contrast between her and Holofernes whose goal was to force the people under the reign of "god" Nebuchadnezzar.

In the end of the narrative, Judith celebrates their victory over the Assyrians with a song. In this song, she repeats what happened and analyzes it. The first part of the song, namely the lines 1-12, recalls the war and its happenings as well as the brutality and violence which the people had to endure (Jdt 16:1-12). These war memories also contain Judith's commitment to the God of Israel who does not lead his people into war but who ends war (16:2 cf. Jdt 9:7, 8). By quoting Exod 15:3 in the LXX-version "The Lord bringing wars to nought, the Lord is his name"

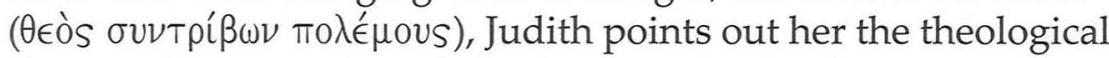
theme. This quotation of Exod 15:3 is the theological theme of the Judith narrative. Unlike Nebuchadnezzar, the true God of Israel does not want war, but wants to end wars. The beginning and the ending of the story are similar: at the beginning of the Judith narrative Nebuchadnezzar spells out his claim of world domination and his dominion as a God which he only can realize by a great war and the killing of many people. At the end of the narrative, Judith prays to the one and only God who, by ending the war, saves his people through the killing of just one man.

\subsection{Conclusion}

The war impressions in the Judith narrative are based on the experiences during the Assyrian time. The Assyrians terrified 
the people, at their time (cf. Isa 5:26-29; 10:13-14) and faced the world with a new kind of imperialism in which politics, trading and military were interlaced with each other. The impact of the Assyrian domination was so strong that it remained influential over centuries - even until the Hellenistic time.

The Book of Judith interprets the conflict as a battle between two "gods". Israel is helpless and inferior to the power of the Assyrian army. Judith realizes this very clearly. That's why she chooses a new and unusual strategy to handle the situation which goes far beyond everything that might be considered as "warfare". But she never does anything on her own, she always relies on God. Her strategy to seduce Holofernes by her beauty and to kill him with his own sword is often called a female plan. Indeed, Judith was wearing a diadem, a festive dress, sandals, rings and earrings to catch the attention of men in order to bewitch them (Jdt 10:3-4). But, first: Judith does not defeat Holofernes with her embellishment, but with his own sword. Second, it is not her seducing beauty, but it is the fact that Judith commits a politically and theologically motivated assassination. The motivation of Judith is due to the political, military and theological threat Israel is facing. Judith's act is a purely political act, and not a female one.

The political motivation of Judith's leads us to a completely new question: Is Judith's murder a tyrannicide? A look into the most famous tyrannicide in antique history might bring about an answer.

\section{Harmodius and Aristogeiton}

The oldest evidence for tyrannicide was found on Attic ground: ${ }^{6}$ Harmodius and Aristogeiton are supposed to be the first tyran-

6 Maybe, one can name an even older evidence for a tyrannicide which is included in the anthology known as Theognis which can be originated in 550 (Theognis 823-824.1179-1182). 
nicides $^{7}$ in history ${ }^{8}$ who are believed to free Athens from the reign of tyranny ${ }^{9}$ by their actions. ${ }^{10}$ Many songs praise these two friends as heroes and present them as role models that represent freedom and democracy in Athens: ${ }^{11}$

I'll wreathe my sword in myrtle bough,

As Harmodius and Aristogeiton did,

When they laid the tyrant low,

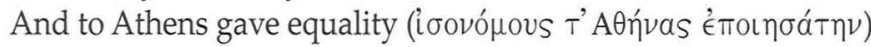

Harmodius, hail! you did not die,

But stay in the islands of the blest,

Where swift-footed Achilles lives,

And Diomedes, Tydeus' brave son.

7 The antique term of tyrannnicide avoids any specific and juridical rating of the act as "murder" but uses the realtively wider expression of "manslaughter". If or when or to which degree a tyrannicide can be considered manslaughter is a theological, ethical and juridical much discussed question.

8 Other tyrant assasins from antiquity are Chion and Leon against the tyrant Learchos (352 B.C.), Timoleon against his brother the tyrant Timophanes of Corinth (365/364 B.C.), Philistus against an unknown tyrant from Erythrae at the time of Alexander the Great, Cylon against the tyrant Aristotimos of Elis (after 272 B.C.).

9 About the development of the tyranny from out of the idea of aristeia and the idea of stasis as well as for an adequate evaluation, cf. SCHLANGE-SCHÖNINGEN, Harmodios und Aristogeiton, die Tyrannenmörder von 514 v. Chr., 17-24.

10 The term "tyrant" (Túpavvos) is a foreign word in Greek. It has a Lydian origin, means "master" in the first place and is used by the Lydain king Gyges for the first time, cf. FADINGER, Griechische Tyrannis und Alter Orient, 265. According to another theory, it belongs to the Tyrrhenian language but also meaning "lord", Lenschau, Tyrannis, 1822. In dawn, it carries the same meaning as basileus and has no negative connotation yet. Only after the development of the Greek democracy, its meaning changes and it turns into a term that stands for autarchy which breaks the actual coonstitution, violate the democratic law and assumes the power (cf. Xenophon, Mem. 4,6,12). Since Plato, the tyrant is an unfair, cruel, egoistic and morally depraved despot (Plato, Resp. 573-574.). Aristotle differentiates the kinds of political rule between number and quantity in kingdom, tyranny/aristocracy, oligarchy and democracy. According to him, tyranny is the rule of one person who is not restricted by any laws and ruling against the wish of the people. The tyrant is not concerned about the public welfare and behaves selfish and acts arbitrarily (Pol. 3,1279-1295).

11 Skolia are drinking songs which are performed at the binge while a myrtle twig is passed around; the one who gets one has to sing a song while he holds the twig in his hands. Already in the 5th century, these skolia were collected in a book, cf. LAMER - KROH, Wörterbuch der Antike, 692. 
I'll wreathe my sword in myrtle bough,

As Harmodius and Aristogeiton did,

When at Athene's feast they slew

Hipparchus, the tyrant of the land.

Harmodius and Aristogeiton, hail!

You will have eternal glory;

Because you laid the tyrant low,

And to Athens gave equality. ${ }^{12}$

The impact of Harmodius and Aristogeiton cannot be undervalued for the self-conception of Athens as that drinking song has the importance of National Anthem today. ${ }^{13}$ Even the comedy poets just mentioned "Harmodius" when they wanted to referred to a tyrannicide. ${ }^{14}$ The act of Harmodius and Aristogeiton developed a massive reception history over centuries and that not only till the Roman time but even until the modern era. ${ }^{15}$

What is so special about the act of Harmodius and Aristogeiton? One needs to differentiate between the reception history of the act and the historical reconstruction of the events. In reception history, Harmodius and Aristogeiton are assumed to be the first tyrant assassins of whom one believed they founded freedom and democracy in Athens. But a historical reconstruction claims that they neither killed a tyrant nor abolished tyranny in Athens nor established the democratic freedom in Athens. There is a striking difference between both ways of understanding the act concerning Harmodius and Aristogeiton. The narrative-mythical arrangement of the act turned it into the paradigm of a tyrannicide until the modern era on the one hand; on the other hand, the historical reconstruction casts a different light on their act. The difference between both ways of understanding is very insightful for the present question.

12 Translation taken from StowAsser, Griechenlyrik in deutsche Verse übertragen, 51.

13 Ehrenberg, Das Harmodioslied, 59.69.

14 Athenaios Deipnos. 10,445-446; 11,503d; Aristophanes, Lys. 632; Ach. 979; 1053; Eq., 763ff.

15 I.e. in HöLDERIN's Hyperion, Frankfurter Ausgabe XVII, $41 \mathrm{ff}$ as well as $443 \mathrm{ff}$. Cf. futher below: the reception of the statue of Harmodius and Aristogeiton in Nationalsocialist Germany and the Sowjet Union. 
During the festival of Panathenae in 514 B.C., the two friends, Harmodius and Aristogeiton, intend to kill the tyrant Hippias and his brother Hipparchus, both sons of the tyrant Peisistratus ${ }^{16}$, who were reigning after his death since 528 B.C. ${ }^{17}$ The reason for their assassination attempt is not only a political one but rather a personal one: Hipparchus, the youngest brother of the tyrant, is attracted to Harmodius and tries to seduce him. Harmodius is loyal to his friend Aristogeiton and remains indifferent to Hipparchus' approaches. Out of disappointment and jealousy, Hipparchus affronts Harmodius' family publicly as Harmodius' sister is not allowed to carry the basket with the sacrificial offerings at the procession of Panathenae which had been promised her before. Hipparchus justifies this by saying that she is not worth of this function. By that, Hipparchus not only affronted Harmodius' sister in public but most of all he questioned her chastity and her sexual integrity which was of high social and moral value for a young unmarried woman in classic Athens. ${ }^{18}$ This insult of his sister appears to be the trigger for the act which Harmodius wants to accomplish with his friend Aristogeiton. They planned to assassinate the two tyrants, Hippias und Hipparchus during the procession at the festival of Panathenae. This opportunity was very convenient as all citizens were allowed to bear arms. Both friends hoped to strike with a small number of conspirators. They planned to kill the tyrant Hippias first and afterwards Hipparchus. But when they thought that their plan was betrayed they just could manage to kill Hipparchus. ${ }^{19}$ So they just succeeded in assassinating Hipparchus but

16 Cf. the reign of Peisistratos: Berve, Die Tyrannis bei den Griechen, 47-77.

17 The oldest reports which reflect the happenings critically were written by Herodotus, Hist. 5,55-61; 6,109.123, Thuc. 1,20; 6,55-61 as well as Ath. Pol. 18. Concerning Athenaion Politeia, cf. RHodes, A Commentary on the Aristotelian Athenaion Politeia; see also: Chambers, Aristoteles. Athenaion Politeia. Thucydides and Athenaion Politeia as well as all additional aknowledgements are discussed in BRUNnSÅKER, The Tyrant-Slayers of Kritios and Nesiotes, 2-19.33-45.

48 Cf. Lavelle, The Nature of Hipparchos' Insult to Harmonios, 318-331. Others link the affront to the lower social status or the orgin, cf. LAvelLE, The Nature of Hipparchos' Insult to Harmonios, 319, n. 5.

19 Cf. Thuc. 6,56-57; Ath. Pol. 18. 
not the tyrant Hippias..$^{20}$ The tyrant Hippias stayed alive and arrested both of them (Thuc. 6,58.2). Harmodius was knifed down by the bodyguards and Aristogeiton was killed after being tortured and interrogated (Ath. Pol. 18).

Through the perspective of the historical reconstructions, Harmodius and Aristogeiton are no real tyrannicides. In trying to assassinate the tyrants, they failed partly and paid with their lives. But immediately, their act was regarded as a tyrannicide and celebrated as tyrannicide; they were turned into heroes and their story was formed into the basic myth of the Athenian democracy. Apart from this legendary arrangement, there have been coeval critical counterparts: Thucydides claims that the enthusiasm of the Athenians is based on their ignorance of the true facts and that the act of Harmodius and Aristogeiton rests upon a love story and is not politically motivated (Thuc. 1,20; 6,53-59). Herodotus emphasizes that Hipparchus was killed but that their act did not abolished tyranny (Hist. 5,55-57; 6,109.123).

Nevertheless, their act was early praised and glorified probably for political reasons: only four years later, in 510, tyranny was abolished by the Spartans (Hist. 5,63,4; Thuc. 6,53.3) and Cleisthenes formed a democracy in Athens. Although the liberation of Athens is historically dated to the year 510, no one remembers this particular year in the cultural memory in Athens, but the year 514 and the legend of the tyrant assassins Harmodius and Aristogeiton. The essential aid of the Spartans is not remembered..$^{21}$

In the following years and centuries, Harmodius and Aristogeiton received great adoration. In the drinking song, Harmodius and Aristogeiton are not only tyrant assassins but they are assigned to the Heroes. ${ }^{22}$ And they are considered to have cre-

20 "Es war wie so oft damals: die mögliche Willkür der Herrscher wurde wirklich unerträglich erst, wo sie tief in das Leben und nicht zuletzt in die Liebe eingriff", MeIER, Ein Neubeginn der Weltgeschichte, 96.

21 Cf. additionally Ath. Pol. 22,3; Podleckr, The Political Significance of the Athenian "Tyrannicide"-Cult, 129-141.

22 "Es folgt im Skolion die Vorstellung, daß die Befreier nicht tot sind, sondern auf den Inseln der Seligen entrückt weiterleben So hoch wird das Verdienst der Tyrannenmörder gewertet, daß man ihm auch im Jenseits eine bevorzugte Stellung verleiht. Nicht mit der großen, unbekannten Masse der Sterblichen kommen die Freunde in den Hades, sondern sie weilen in der Gesell- 
ated "freedom and equality", isonomia, in Athens. ${ }^{23}$ In this context, justice is the virtue of the communal life while tyranny is a despicable crime on the background of the isonomia which is evident through pleonexia, outrageous greed. In this perspective, tyranny destroys the communal life and democracy.

Within the following years and centuries, laws against tyranny were formed as well as the admiration of Harmodius and Aristogeiton was staged by exceptional privileges in public. Firstly, their descendents received special treatment by the government. Their food was provided by the state. They were tax-exempt and were allowed to sit in the front row in theaters. Secondly, one of the highest magistrates of Athens donated an oblation for Harmodius and Aristogeiton which was normally an honor that was subjected to the Athenians who lost their lives in fighting for their country. So, Harmodius and Aristogeiton were on one par with the killed soldiers of Marathon and Salamis. ${ }^{24}$ Thirdly, it was forbidden to name a slave after them and to make fun of them. ${ }^{25}$ Fourthly, statues were placed publically. Shortly after the banishment of the tyrants (after 510 B.C.), Antenor created a group of bronze statues depicting the tyrant assassins Harmodius and Aristogeiton by a public request. This group was placed at the Agora close to where they perpetrated the assassination. ${ }^{26}$ These statues of Harmodius and Aristogeiton were the only sculptures depicting humans next to the gods statues on the Agora and remained the only ones for a long time. ${ }^{27}$ Therefore, this group can be named "das erste Beispiel

schaft der berühmtesten Helden der Vorzeit" ${ }^{\prime}$, FrIEDEL, Der Tyrannenmord in der Gesetzgebung und Volksmeinung der Griechen, 39.

23 In the skolion, the basic term of the Greek Polity Isonomia is mentioned which guarantees equal attendance at political life of all fully fledged citizens and the equality of these citizens before the law, cf. Ehrenberg, Das Harmodioslied, 67-69.

24 Ath. Pol. 58,1; TAYlor, The Tyrant Slayer, 18.

25 Cf. Aulus Gellius, Noct. Att. 9,2.10; Hyper. 2,3; cf. on this Taylor, The Tyrant Slayer, 27.

26 Cf. Pausanias, Descr. I,8,5; Plinius, Nat. 34,16-17, cf. on this and additional sources BrunnsÅke, The Tyrant-Slayers of Kritios and Nesiotes, 39-44; TAYLOR, The Tyrant Slayer, 34.

27 Demosthenes, 1-2 Aristog. 20; TAylor, The Tyrant Slayer, 37-46. 
eines politischen Denkmals in Europa"28. The original sculpture does not exist anymore as it was taken away by the Persian king Xerxes. Nevertheless, the Athenians were able to set up a new group of tyrant assassins at the Orchestra on the Agora in $477 / 476$ B.C., namely the group of Kritios and Nesiotes. ${ }^{29}$ The image of the liberators was one of the most important issues of the recommencement after Xerxes. ${ }^{30}$ Another emphasis of the statues group's importance was the prohibition to place any other statue near to them. ${ }^{31}$

Apart from the way Harmodius and Aristogeiton were honored, a form of oaths was passed on during the period of Cleisthenes' reforms (about 500) right after the Athenian tyranny which was formed to manage the behaviour of the citizens regarding tyranny. ${ }^{32}$ A tyrant assassin is regarded as "justified"

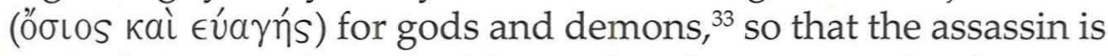
not only exempt from punishment but does not need to face any religious atonements like someone who acted in self-defence, too. ${ }^{34}$ Harmodius and Aristogeiton are mentioned in this oath explicitely. Comparable to this oath is the Athenian people's de-

28 LAMER - KROH, Wörterbuch der Antike, 37.

29 The new group is different because they do not stand next to each other. They are depicted in the moment of action. Today, it is located in the National museum of Naples. The correct classification is debateable. For reconstructional and interpretational purposes of this group, cf. ERNST, Die Tyrannen-Mörder, 3-31; SCHeFold, Die Tyrannenmörder, 189-202, Fornara, The Cult of Harmodius and Aristogeiton, 155-180; FeHR, Der Tyrannentöter, 5-54. The - in the19 ${ }^{\text {th }}$ century rediscovered-group was used and received for their own purposes by the Nationalsocialists in Germany and by the Sowjets in the Sowjet Union in the $20^{\text {th }}$ Century, cf. FeHR, Der Tyrannentöter, 55-68; BRUnNSÅKER, The Tyrant-Slayers of Kritios and Nesiotes, 33.

30 MeIER, Ein Neubeginn der Weltgeschichte, 302.

31 This was only worked-open for the cult of Demetrius I and his father Antigonus I Monophthalmus, the saviors of Athens, in 307 B.C. and for Cassius and Brutus 42 B.C., cf. Schlange-Schöningen, Harmodios und Aristogeiton, die Tyrannenmörder von $514 \mathrm{v}$. Chr., 31.

32 The set phrase itself is not traditional, but it can only be taken from the Act of 410, cf. translation by FRIEDEL, Der Tyrannenmord in der Gesetzgebung und Volksmeinung der Griechen, 41-42.

33 ö $\sigma$ los refers to everything that was accepted in case of godly justice and therefore convenient for the God. In the case of Evarńs, a cultic purity is meant.

34 Cf. Friedel, Der Tyrannenmord in der Gesetzgebung und Volksmeinung der Griechen, 41.45. 
cision on Erythrae (about 470-465), shortly after Erythrae joined Attic Sea Alliance, to protect its democracy as well as the Tyrant Act of Ilion (in 275). Wreaths made of olive branches are another traditional honor for the fighting opponents of tyranny. ${ }^{35}$

\section{Judith's act as a political assassination}

When Caesar was killed by Cassius and Brutus on the Ides of March 44 B.C., the Athenians honored the tyrant assassins and Caesar murderers, if nothing else but to position themselves politically according to the new situation, in positioning two statues for them next to Harmodius and Aristogeiton at the Agora and enobled them equivalently. ${ }^{36}$ This example proves the importance of the tyrant assassins Harmodius and Aristogeiton for the identity as well as for over centuries existing continuum of tradition. The tyrant assassins Harmodius and Aristogeiton were promoted to a fundamental story in which basic developments were classified and by which these developments could be understood and analyzed.

This background information gives the Judith narrative a completely different context. It is not at all a story of a disappointed sexual experience like Hebbel and Freud tried to domesticate the biblical narrative, but it is rather a political act whose significance becomes clear considering the antique context of the tyrannicide. As Harmodius and Aristogeiton, who are memorized as heroes in Greek and Roman cultural memory, there are plenty of parallels to the Book of Judith.

First, there are always two actors: Judith and her servant just as Harmonodius und Aristogeiton. Second, another resemblance is given through the sexual demands: Hipparchus demands it from Harmodius, Holofernes from Judith. Third, Judith is given a wreath to honor her for her tyrannicide. This wreath is described explicitly as a wreath consisting of olive branches (Jdt 15:15, 13) - just as tyrant murders are honored in Greece. Fourth,

35 FRIEDEL, Der Tyrannenmord in der Gesetzgebung und Volksmeinung der

- Griechen, 60.

36 Cf. Cassius Dio, Hist. 47,20.4. Shortly after Caesar's assassination, came to Athens, possibly, cf. Bellen, Das Königtum im Geschichtsbewußtsein des republikanischen Staates, 35-45, 39. 
it is stressed that Judith is still pure and not guilty - just as the tyrannicides in Athens. Fifth, the act of Harmodius and Aristogeiton and accordingly the act of Judith and her servant are justified through their theological and political ideals: Harmodios and Aristogeiton are seen as founders of the democracy in Athens, Judith and her servant save the people of Israel against Nebuchadnezzar's claim of being worshipped as the true and only God. Sixth, Harmodius and Aristogeiton are honored by the public placing of the statues. The Judith narrative also contains a public honoring of its protagonist; first of all, she is visited in Betulia by the high priest and the council of elders from Jerusalem (Jdt 15:8-10), and finally the story ends with the festival in Jerusalem (Jdt 16:21-25). The Judith narrative emphasizes that Judith will be remembered forever (cf. Jdt 15:10; cf. 8:32). Seventh, in the Judith narrative and also in the case of Harmodius and Aristogeiton, the moment of the act has caught a lot of attention in the reception history in art, literature etc.

As in the case of Harmodius and Aristogeiton and of Cassius and Brutus, although they were supported by a circle of conspirators, these pairs are memorized as heroes in the cultural memory; one has a pair formation in the Judith narrative as well: Judith and her servant. As in the case of Hipparchos and Harmodius, sexual demands of Holofernes belong to the vicinity of Judith's act. Judith was given a wreath to honor her for her tyrannicide as the tyrant assassins were honored, too. This wreath is described explicitly as a wreath consisting of olive branches (Jdt 15:13) - just as tyrant murders are honored in Greece.

Interestingly, the connection between the Judith narrative and the story of Harmodius and Aristogeiton was already a topic in the early reception history. In his reasoning of perfection which can be achieved similarily by men and women, Clement of Alexandria (+220) lists Judith next to Moses (Strom. IV 118) as an example for a woman who achieved perfection. He further names non-biblical female characters and the Athenian Leaina at first place. Leaina belonged to the circle of conspirators of Harmodius and Aristogeiton who remained silent about the attempted assassination of Hipparchus while being tortured (Strom. IV 120). Clement of Alexandria's example not only 
proves that one still remembered - after 700 years - the classical tyrant assassins Harmodius and Aristogeiton, but that Clement saw Judith as part of the tyrannicide context. ${ }^{37}$ Another example taken from reception history is the bronze sculpture of Judith which was made by Donatello (1387-1466) in 1459 on behalf of Piero de Medici. The inscription at the base of the sculpture ${ }^{38}$ was changed after the banishment of the Medici and symbolizes nowadays the political and civil freedom of Florence (1494). ${ }^{39}$ Interestingly, the non-theological literature that deals with tyrannicides always uses the Judith narrative as a typical biblical example. ${ }^{40}$

\section{Conclusion}

If Judith's act belongs to the pagan tradition of politically-motivated assassinations, one can see how Judith's act can also be considered as a political act and much more than just a helpless try of a woman to save Israel by using her femininity. In our case, we have two women who are politically active to intervene, to be a "spoke in the wheel" ${ }^{41}$ Of course, murder can never be a morally legitimate mean $\mathrm{s}^{42}$; nevertheless, the tyrannicide is a "je einen Not- und Sonderfall dar, in dem sich das Drama der Geschichte ungleich verdichtet. Wo sich das künftige Geschick unzähliger Menschen und Völker durch den Tod eines einzigen Menschen zu wenden scheint, stellen sich ganz neue Fragen an Akteure und Zuschauer und deren Moral." 43

37 Origen not only lauds Judith (Hom. 9 Judic.; Hom. 19 Jer.) but Ehud as well who killed the Moabite king Eglon by sword (Judg 3:12-30); he sees it as a tyrannicide. Origen assesses it accretively and morally approves of it (Hom. 4 Judic.). It is not known whether or not Origen would have approved of it if the tyrannicide had been committed by a Christian, cf. i.e. Cels. 3,7.

38 "Kingdoms fall through luxury [sin], cities rise through virtues. Behold the neck of pride severed by the hand of humility."

39 Friedman, The Metamorphoses of Judith, 236.

40 Cf. i.e. BAuer, Widerstand gegen die Staatsgewalt, 19.21-22; Ford, Political Murder, 9-11; Turchetri, Tyrannie et tyrannicide de $1^{\prime}$ Antiquité à nos jours, 194.546.

41. This is how Dietrich Bonhoeffer stated it in his "Die Kirche vor der Judenfrage $^{\prime \prime}$ in 1933.

42 Cf. on this Breuer, Die Tyrannentötung, 280-281.

43 Hoffmann, Das Recht zum Widerstand, 312. 
The Judith narrative introduces its readers to such a drama of a constructed story in which one goes through a situation of an extraordinary threat by using the fictional mode of the story. Facing the threat of Nebuchadnezzar's world domination and deity claims, the text of the Judith narrative develops a theological-anthropological mode $\mathrm{l}^{44}$ that does not need God to intervene like deus ex machina in the happenings, but it stresses the fact that humans reconnect themselves with God and it enables them to act and to take risks at their own expenses and become guilty. This is the quintessence of the Judith narrative which furthermore underlines the fact that the book of Judith is only a warlike book at the first glimpse. The total war and the totalitarian claim of world domination and deity of Nebuchadnezzar are the most terrible and devastating catastrophe which is thoughtout fictionally and run through in the Judith narrative to discuss possible rooms of manoeuvre. Even in the case of such a brutal violence and war experience, it is the most important and twice stated message of the narrative that Israel does not worship a god who wants a war but Israel worships a god who ends wars (Jdt 9:7-8; 16:3). Contrary to all expectations, the Judith narrative cannot be considered to be war propaganda. The narrative rather represents what Stephan Märki, the director of the German National Theater in Weimar, calls the job of art: "In der Kunst werden spielerisch Sichtweisen vorgeschlagen, die oft mit den dominierenden Argumentationsschemata wenig zu tun haben, ihnen gar widersprechen. Kunst ist deshalb der Spielraum der Freiheit. [...]. Kunst und Theater bieten einen Raum an, wo solcher Gewalt im Spiel widersprochen wird: einen ästhetischen Übungsraum für die Zivilgesellschaft." ${ }^{45}$

\footnotetext{
44 Cf. on this Schmitz, Gedeutete Geschichte, 460-462.

45 MärkI, Spielraum der Freiheit, on November 12th, 2008 printed in the Süddeutschen Zeitung Nr. 263, 17.
} 


\section{Bibliography}

BAUER, F., Widerstand gegen die Staatsgewalt, Frankfurt a.M.: FischerBücherei, 1965.

Bellen, H., Das Königtum im Geschichtsbewußtsein des republikanischen Staates. Ein Kontinuumsproblem der römischen Geschichte, in: ID., Politik - Recht - Gesellschaft. Studien zur Alten Geschichte (Historia Einzelschriften 115), Stuttgart: Steiner-Verlag, 1997, 35-45.

Berve, H., Die Tyrannis bei den Griechen, München: Beck, 1967.

Breuer, C., Die Tyrannentötung. Ein sozialethisches und moraltheologisches Problem: Die Neue Ordnung 56 (2002) 280-293.

BRUNNSÅKer, S., The Tyrant-Slayers of Kritios and Nesiotes. A Critical Study of the Sources and Restoration, Stockholm: Swedish Institut, ${ }^{2} 1971$.

Buschor, E., Die Tyrannen-Mörder (Sitzungsberichte der Bayrischen Akademie der Wissenschaften. Philosophisch-historische Abteilung 5), München: Bayrische Akademie der Wissenschaften, 1940, 3-31.

Chambers, M., Aristoteles. Athenaion Politeia, Darmstadt: Wissenschaftliche Buchgesellschaft, 1990.

EhrenberG, V., Das Harmodioslied: Wiener Studien 69 (1956) 57-69.

Engel, H., Das Buch Judit, in: E. Zenger (ed.), Einleitung in das Alte Testament, Stuttgart - Berlin - Köln: Kohlhammer, ${ }^{72008, ~ 289-301 . ~}$

Fadinger, V., Griechische Tyrannis und Alter Orient, in: K. RaAflaub (ed.), Anfänge politischen Denkens in der Antike (Schriften des Historischen Kollegs Kolloquien 24), München: Oldenbourg, 1993.

FeHr, B., Der Tyrannentöter. oder: Kann man der Demokratie ein Denkmal setzen?, Frankfurt a.M.: Fischer-Taschenbuch-Verlag, 1984, 5-54.

Ford, F.L., Political Murder. From Tyrannicide to Terrorism, Cambridge, Mass. (et al.): Harvard University Press, 1985, 9-11.

Fornara, Ch.W., The Cult of Harmodius and Aristogeiton: Philologus 114 (1970) 155-180.

FrIEDEL, H., Der Tyrannenmord in der Gesetzgebung und Volksmeinung der Griechen (Würzburger Studien zur Altertumswissenschaft), Stuttgart: Kohlhammer, 1937.

Friedman, M., The Metamorphoses of Judith (FS Narkiss): Jewish Art 12/13 (1987) 225-246.

Hoffmann, H., Das Recht zum Widerstand. Vom Tyrannenmord zur mittelalterlichen und neuzeitlichen Widerstandslehre: Europäische Wehrkunde 31 (1982) 312-318.

JonAs, H., Die Lehre vom Tyrannenmord in der Antike. Inaugural-Dissertation zur Erlangung der Doktorwürde einer Hohen Rechtswissenschaftlichen Fakultät der Universität Köln, 1947.

Lamer, H. - KRoh, P., Wörterbuch der Antike, Stuttgart: Kröner, ${ }^{9} 1989$.

Lavelle, B.M., The Nature of Hipparchos' Insult to Harmonios: American Journal of Philology 107 (1986) 318-331. 
Lenschau, Th., Tyrannis, in: PRE II.14, Stuttgart, 1948, 1821-1842, 1822.

MÄrkI, S., Spielraum der Freiheit, am 12. November 2008 in der Süddeutschen Zeitung Nr. 263, 17.

MeIer, Ch., Athen. Ein Neubeginn der Weltgeschichte, Berlin: Siedler, 1993. Podlecki, A.J., The Political Significance of the Athenian 'Tyrannicide'Cult: Historia 15 (1966) 129-141.

Rhodes, P.J., A Commentary on the Aristotelian Athenaion Politeia, Oxford: Clarendon Press, 1981.

SCHEFold, K., Die Tyrannenmörder: Museum Helveticum 1 (1944) 189-202.

Schlange-Schöningen, H., Harmodios und Aristogeiton, die Tyrannenmörder von 514 v. Chr., in: A. Demandt (ed.), Das Attentat in der Geschichte, Augsburg: Böhlau, 2000, 15-37.

Schmitz, B., Gedeutete Geschichte. Die Funktion der Reden und Gebete im Buch Judit (HBS 40), Freiburg: Herder, 2004.

Stowasser, J.M., Griechenlyrik in deutsche Verse übertragen, Heidelberg: Winter, 1909.

TAYLOR, M.W., The Tyrant Slayer. The Heroic Image in Fifth Century B.C., Athenian Art and Politics, New York: Arno Press, 1981.

Turchettr, M., Tyrannie et tyrannicide de l'Antiquite à nos jours, Paris: Presses Universitaires de France, 2001. 